\title{
A Study of Job Satisfaction of Academicians
}

\author{
Bhavik U Swadia ${ }^{1} \&$ Jaimin Patel ${ }^{1}$ \\ ${ }^{1}$ Faculty of Commerce, GLS University, Ahmedabad, India \\ Correspondence: Dr. Jaimin Patel, Assistant Professor, Faculty of Commerce, GLS University, Ahmedabad, Gujarat, \\ India.
}

Received: February 27, 2019

Accepted: September 25, 2019

Online Published: November 25, 2019

doi:10.5430/jms.v10n5p40

URL: https://doi.org/10.5430/jms.v10n5p40

\begin{abstract}
Every management face challenges daily, but there are some challenges which are customary to every management. One from such common problems confronted by the management while managing employees (teachers) include Job satisfaction \& Employee Loyalty. The invaluable resource that any institute possesses is its work force; indeed, an employee's longer work experience at the same corporate enhances his worth. The primary qualities a teacher possesses include being introspective, being cooperative, being directive and being expressive. A syllabus which is effective and a curriculum that is well planned is only fruitful with availability of teachers who are meticulous in their duties. Knowledge alone cannot be the basis for gauging the ability of a teacher. There are other factors too like whether the teacher is comfortable in handling the profession that impacts the effectiveness of the system. With many research works having taken place in this zone with multiple organizations, what we lack is a distinct research on satisfaction at job which needs to be taken up.
\end{abstract}

Hence, we conducted a research where we took a sample size containing 50 teachers and performed the survey on the premise of systematic sampling. The method followed in the process of acquiring and assembly of data was structured questionnaire method.

Keywords: teacher, job satisfaction, teamwork, development and training

\section{Introduction}

Defining the scope of teaching or giving it a terminology is nothing but next to impossible as it has been influenced by various political \& social factors of the country which has made it an altogether social process. So, try to contemplate over the various definitions given to teaching by academiciansm, which are listed below:

As per the definition given by Gage, "Teaching is a form of interpersonal influence aimed at changing the behavior potential of another person."

According to Ryans, "Teaching is concerned with the activities which are concerned with the guidance or direction of the learning of others."

Job satisfaction and Job productivity have an inter dependent relationship. Therefore, a direct relationship is witnessed here as with enhanced degree of satisfaction at jobs, there exists enhanced productivity at job. Here, the satisfaction enjoyed by a person while engaging in a job has a direct relation with the satisfaction he enjoys in his life. Different non-academic management literatures and media papers have discussed the link between satisfaction at a job and the performance delivery in the same manner.

Hence, most of the measures inference that satisfaction in job for employees is one of the vital factors behind an employee's motivation, his objective accomplishment and his positive behavior. This explanation does not conclude that a satisfied employee is always a good achiever or an excellent performer, but a dissatisfied employee will always cause damage that would be hard to repair for the organization.

\subsection{Job Satisfaction}

An individual's degree of fulfillment or satisfaction in his job is what defines job satisfaction. This is also termed as the taste or distaste a person carries towards his job. There exist 2 categories in job satisfaction which include "Affective job satisfaction" and "Cognitive job satisfaction". So, on one hand there is affective job satisfaction which is related with the gratification a person develops towards his job while on the other hand cognitive job satisfaction deals with various magnitudes of job such as work hours, salary, promotion and increment process, development of 
career, agreements relating to pension and multiple other aspects of job. The concept of job satisfaction is composite, multifaceted and subjective which is to say that the reasons for the satisfaction experienced by one person may differ to another person engaging in an equal activity. Though in general, satisfaction in a job and motivation that an employee receives are interlinked but the kind of the relationship they exchange cannot be determined. One cannot say, motivation is similar to satisfaction. Satisfaction generally deals with the attitude and the inner state of an employee. But in almost every instance it could be linked with the personal feeling that an employee experiences while achieving something, may it be qualitative or quantitative (Mullins, 2005).

\section{Literature Review}

(1) Sashikanta Khuntia, Subhodip Adhikary (2015)

The basic qualities a teacher possesses include being introspective, being cooperative, being directive and being expressive. For making the educational system a success what is most required is an effective teacher's presence. A syllabus which is effective and a curriculum that is well planned is only successful if there exist teachers who are meticulous in their duties.

Knowledge alone cannot be the determining factor to assess the ability of a teacher, there are other factors too which influence like whether the teacher is comfortable in handling the profession. Many external factors also influence the comfort of the teacher while performing his duties. At present teachers are dissatisfied being the fabricator of economic development and social development. Hence the profession is observed to have a deficiency in the talent pool. This research study mainly gives emphasis to:-

- Job Satisfaction and its various strands.

- The effect that unique facets of job satisfaction has above the degree of job satisfaction of teachers.

- The degree to which a teacher performs his functions

Chi-square test of association and multiple regression analysis for data analysis are the 2 statistical techniques that have been used in this study.

(2) Rajput, S., Singhal, M., \& Tiwari, M. S. (2016)

There is a strong association between satisfaction in a job and loyalty of the workforce. A range of researches stand as evidence to prove the impact that job satisfaction has on employee loyalty. The success of any organization depends on the employee's loyalty and how committed he is in performing his activities. Finding the impact of job satisfaction on employee loyalty in case of educationalists was the purpose or idea behind this study. Multiple factors that underlie job satisfaction and employee loyalty are studied here. The questionnaire survey was used for achieving the aim of the study. The outcome of the researches conducted concludes that job satisfaction has no impact on employee loyalty when it comes to an academician.

(3) Ekta Sinha (2013)

Here the work of research encounters with the measurement of the degree of satisfaction in the employees with unique reference to KRIBHCO, Surat. Retention of skillful and hard working employees who contribute in attainment of goals of the corporation and customer satisfaction is very much a necessity for remaining relevant in the competitive market. With many research works having taken place in this area with different organizations, what we lack is this particular research that requires to be held as it's been never conducted earlier at KRIBHCO, Surat. Hence, we conducted a research where we took a sample size containing Hundred and Fifty employees and performed the survey on the premise of systematic sampling. The method followed in the process of data assembly and accumulation was structured questionnaire method on Likert five point scale for 23 major variables which had been reduced to 5 factors such as

1) Work relation,

2) Empowerment and Working environment,

3) Pay and future prospects,

4) Training and work environment

5) Job Rotation

On the premise of the research conducted it was discovered that the work force was satisfied when all the 5 factors mentioned above were considered. IBM SPSS 20 was the machine that was used for accomplishing the motive of data analysis. For reducing the data the factor analysis was performed along with non-parametric tests such as the 
Kruskal-Wallis and Mann Whitney Rank test.

For determining the degree of satisfaction within the employees against each essential variable found after dimension reduction the tests that was held was Chi-square tests.

(4) Rizwan, Khan, Tariq, Ghaffar, Anjum, Bajwa (2012)

The crux of this research report was to identify the problems that the employees encountered while working at organizations and discovering methods to keep the loyalty of the workforce towards their organization alive. The objective behind this research was to identify and address the cue that aides in enhancing the satisfaction of the workforce which would hence increase the productivity. Some of the factors identified include:

1) Environment that worker works in

2) Bonuses and rewards offered

3) An employee's recognition in the management

4) The process to train and develop an employee

5) Team work

Such factors aid in making the policies effective and as an outcome the management becomes efficient. Theoretical considerations are the basis on which this research papers got created. It was premised on a model that proposed the linking of employee job satisfaction (EJS) constructs. A 2012 survey that was held in Punjab of Pakistan covered almost 200 employees within the territory. This survey is a perfect example to establish the strong relationship between team work and all other factors.

(5) Brikend Aziri, (2011)

The discoveries from the study highlighted the factors that influence the workforce's satisfaction and they were such as

1) The environment of work

2) Opportunities offered for advancement

3) Management

4) Pay

5) Work groups and work conditions.

This is a vital challenge that today's organizations come across. Satisfaction in job is primarily a composition of the positive and the negative feelings that a worker has towards his work.

A composition of both "+" and "-." feelings that a worker experiences while working at his workplace determines his job satisfaction. A persons satisfactory level while working also gets influenced by factors like his need, desire and the experiences he goes through on a daily basis while working at the organization. Job satisfaction of an employee is based on the relationship between the expectations the employee has from the management and how much of it has been fulfilled.

(6) Kabir and Parveen (2011)

Their study brought into light that the utmost requirement for any organization's enhanced performance lies with the manager's ability to identify various factors that effect and enhance the gratification of an employee in his job.

\subsection{Research Objective}

(1) Observing and understanding the association between job gratification and performance.

(2) Observing and understanding the major factors responsible for job gratification.

(3) Determining the influence of job gratification dimensions on satisfaction in a job.

\section{Research Methodology}

The subject of the study concentrated on academicians in Gujarat. The prime objective of the study conducted was to assess the impact job satisfaction has on the employees and also to understand the relationship job satisfaction has with loyalty of the employees (academicians). The data was collected from the academicians working in various institutes for fulfilling this purpose. Primary data was the basis on which this research was conducted. Structured questionnaire method was followed for the purpose of data collection.

The questionnaire was based on 5-point (Likert) scale ranging from 1= Highly Dissatisfied to 5= Highly Satisfied. In 
this study, convenient sampling technique was used. The sample size used for the purpose of this study was 100 employees.

1. Relation Between the Gender and Job Satisfaction Level

$\mathrm{HO}$ : There is no significant relation between the gender and job satisfaction level

H1: There is significant relation between the gender and job satisfaction level

Table 1. Chi-Square tests

\begin{tabular}{llll}
\hline & Value & df & Asymp. Sig. (2-sided) \\
\hline Pearson Chi-Square & $407.350^{\mathrm{a}}$ & 4 & .000 \\
\hline Likelihood Ratio & 545.088 & 4 & .000 \\
\hline Linear-by-Linear Association & 340.849 & 1 & .000 \\
\hline N of Valid Cases & 50 & & \\
\hline a. 0 cells $(0.0 \%)$ have expected count less than 5. The minimum expected count is 33.86. \\
\hline
\end{tabular}

From the above Table 1 Pearson Chi-Square statistic table it can be seen that $X^{2}=407.350$, and $p<0.05$, such data revealed that null hypothesis is rejected and there exists a significant relationship between the gender and job satisfaction level.

2. Relation Between the Age and Job Satisfaction Level

H0: There is no significant relation between the age and job satisfaction level

$\mathrm{H} 1$ : There is significant relation between the age and job satisfaction level

Table 2. Chi-Square tests

\begin{tabular}{llll}
\hline & Value & $\mathrm{df}$ & Asymp. Sig. (2-sided) \\
\hline Pearson Chi-Square & $1312.894^{\mathrm{a}}$ & 12 & .000 \\
\hline Likelihood Ratio & 1119.838 & 12 & .000 \\
\hline Linear-by-Linear Association & 484.160 & 1 & .000 \\
\hline $\mathrm{N}$ of Valid Cases & 50 & & \\
\hline a. 0 cells $(0.0 \%)$ have expected count less than 5. The minimum expected count is 11.29. \\
\hline
\end{tabular}

From the above Pearson Chi-Square statistic Table 2 it can be seen that $X^{2}=1312.894$, and $p<0.05$, such data revealed that null hypothesis is rejected and there exists a significant relationship between the age and job satisfaction level.

3. Relation Between the Education Qualification and Job Satisfaction Level

H0: There is no significant relation between the education qualification and job satisfaction level

H1: There is significant relation between the education qualification and job satisfaction level

Table 3. Chi-Square tests

\begin{tabular}{llll}
\hline & Value & df & Asymp. Sig. (2-sided) \\
\hline Pearson Chi-Square & $1161.520^{\mathrm{a}}$ & 16 & .000 \\
\hline Likelihood Ratio & 1086.277 & 16 & .000 \\
\hline Linear-by-Linear Association & 477.040 & 1 & .000 \\
\hline N of Valid Cases & 50 & & \\
\hline a. 5 cells $(20.0 \%)$ have expected count less than 5. The minimum expected count is .85. \\
\hline
\end{tabular}


From the above Pearson Chi-Square statistic Table 3 it can be seen that $\mathrm{X}^{2}=1161.520$, and $\mathrm{p}<0.05$, such data revealed that null hypothesis is rejected and there exists a significant relationship between the education qualification and job satisfaction level.

4. Relation Between the Length of Service and Job Satisfaction Level

H0: There is no significant relation between the length of service and job satisfaction level

$\mathrm{H} 1$ : There is significant relation between the length of service and job satisfaction level

Table 4. Chi-Square tests

\begin{tabular}{llll}
\hline & Value & df & Asymp. Sig. (2-sided) \\
\hline Pearson Chi-Square & $1425.662^{\mathrm{a}}$ & 20 & .000 \\
\hline Likelihood Ratio & 1254.706 & 20 & .000 \\
\hline Linear-by-Linear Association & 501.947 & 1 & .000 \\
\hline N of Valid Cases & 50 & & \\
\hline a. 0 cells $(0.0 \%)$ have expected count less than 5. The minimum expected count is 7.48. \\
\hline
\end{tabular}

From the above Pearson Chi-Square statistic Table 4 it can be seen that $X^{2}=1425.662$, and $p<0.05$, such data revealed that null hypothesis is rejected and there exists a significant relationship between the length of service and job satisfaction level.

5. Relation Between the Subject Area and Job Satisfaction Level

H0: There is no significant relation between the subject area and job satisfaction level

$\mathrm{H} 1$ : There is significant relation between the subject area and job satisfaction level

Table 5. Chi-Square tests

\begin{tabular}{llll}
\hline & Value & df & Asymp. Sig. (2-sided) \\
\hline Pearson Chi-Square & $1096.577^{\text {a }}$ & 16 & .000 \\
\hline Likelihood Ratio & 1042.652 & 16 & .000 \\
\hline Linear-by-Linear Association & 447.176 & 1 & .000 \\
\hline N of Valid Cases & 50 & & \\
\hline a. 0 cells $(0.0 \%)$ have expected count less than 5. The minimum expected count is 8.18. \\
\hline
\end{tabular}

From the above Pearson Chi-Square statistic Table 5 it can be seen that $X^{2}=1096.577$, and $p<0.05$, such data revealed that null hypothesis is rejected and there exists a significant relationship between the subject area and job satisfaction level.

6. Relation Between the Monthy Salary and Job Satisfaction Level

H0: There is no significant relation between the monthly salary and job satisfaction level

H1: There is significant relation between the monthly salary and job satisfaction level

Table 6. Chi-Square tests

\begin{tabular}{llll}
\hline & Value & df & Asymp. Sig. (2-sided) \\
\hline Pearson Chi-Square & $1298.974^{\mathrm{a}}$ & 16 & .000 \\
\hline Likelihood Ratio & 1186.950 & 16 & .000 \\
\hline Linear-by-Linear Association & 488.877 & 1 & .000 \\
\hline N of Valid Cases & 50 & & \\
\hline a. 0 cells (0.0\%) have expected count less than 5. The minimum expected count is 10.02.
\end{tabular}


From the above Pearson Chi-Square statistic Table 6 it can be seen that $X^{2}=1298.974$, and $p<0.05$, such data revealed that null hypothesis is rejected and there exists a significant relationship between the monthly salary and job satisfaction level.

7. How Do You Satisfied With Your Basic Pay?

H0: Primary Teachers are not satisfied with their basic pay

H1: Primary Teachers are satisfied with their basic pay

Table 7. One-Sample statistics

\begin{tabular}{lllll}
\hline & $\mathrm{N}$ & Mean & Std. Deviation & Std. Error Mean \\
\hline How Do You Satisfied With Your Basic Pay? & 50 & 2.91 & 1.227 & .052 \\
\hline
\end{tabular}

Table 8. One-Sample test

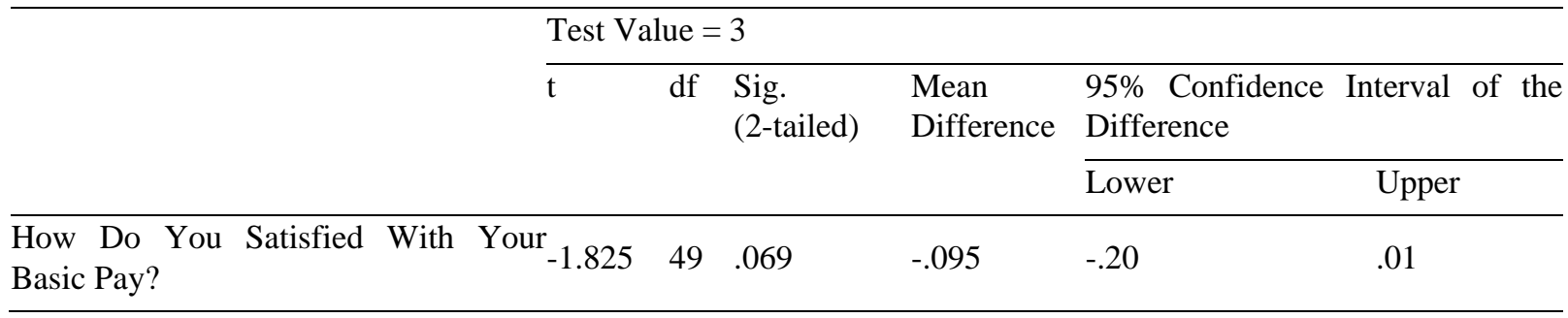

From the above Table 8 we can conclude that null hypothesis is accepted. Significance value is 0.069 which is greater than standard value 0.05 . So Primary Teachers are not satisfied with their basic pay.

8. How Do You Satisfied With Your Allowance?

H0: Primary Teachers are not satisfied with their allowance

H1: Primary Teachers are satisfied with their allowance

Table 9. One-Sample statistics

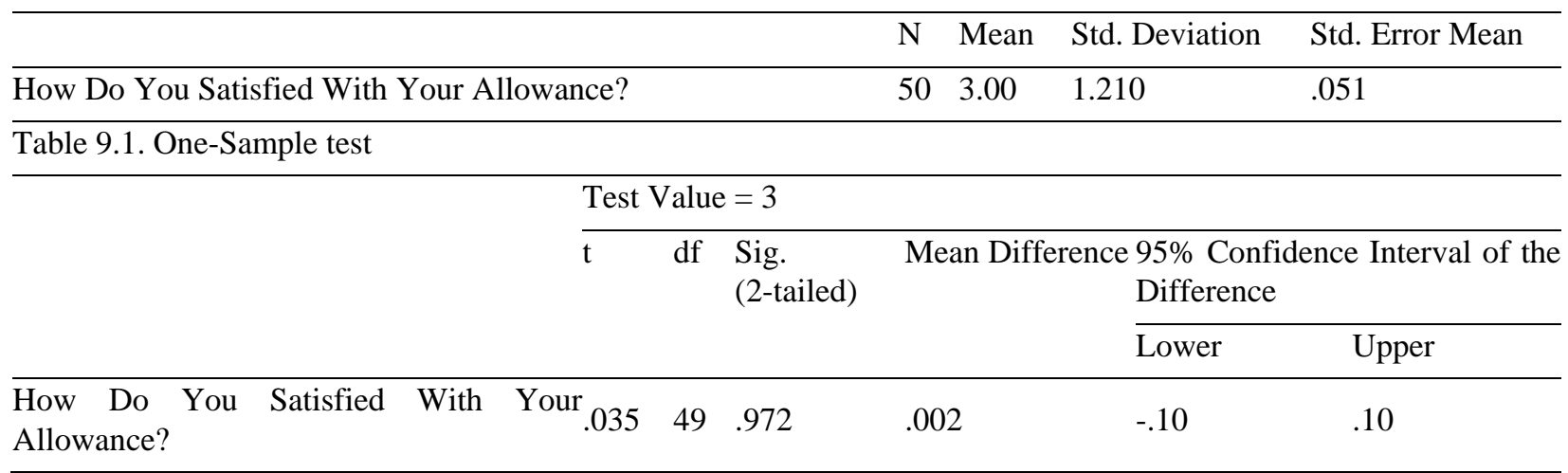

From the above table 9.1 we can say that null hypothesis is accepted. Significance value is 0.972 which is greater than standard value 0.05 . So Primary Teachers are not satisfied with their allowance

9. How Do You Satisfied With Promotion System for Higher Qualifications??

H0: Primary Teachers are not satisfied with promotion system

H1: Primary Teachers are satisfied with promotion system 
Table 10. One-Sample statistics

\begin{tabular}{llllllllll}
\hline & & & N & Mean Std. Deviation Std. & $\begin{array}{c}\text { Error } \\
\text { Mean }\end{array}$ \\
\hline $\begin{array}{l}\text { How Do You Satisfied } \\
\text { Qualifications? }\end{array}$ & & & & & & & \\
\hline
\end{tabular}

Table 11. One-Sample test

\begin{tabular}{|c|c|c|c|c|c|c|}
\hline & \multicolumn{6}{|c|}{ Test Value $=3$} \\
\hline & & \multirow[t]{2}{*}{ df } & \multirow[t]{2}{*}{$\begin{array}{l}\text { Sig. } \\
\text { (2-tailed) }\end{array}$} & \multirow[t]{2}{*}{$\begin{array}{l}\text { Mean } \\
\text { Difference }\end{array}$} & \multicolumn{2}{|c|}{$\begin{array}{l}95 \% \text { Confidence Interval } \\
\text { of the Difference }\end{array}$} \\
\hline & & & & & Lower & Upper \\
\hline $\begin{array}{l}\text { How Do You Satisfied With Promotion System } \\
\text { for Higher Qualifications? }\end{array}$ & -1.647 & 49 & .100 & -.089 & -.20 & .02 \\
\hline
\end{tabular}

From the above Table 11 we can say that null hypothesis is accepted. Significance value is 0.1000 which is greater than standard value 0.05 . So Primary Teachers are not satisfied with their promotion system.

10. Are You Satisfied With the Infrastructure of the School?

H0: Primary Teachers are not satisfied with the infrastructure of the school

H1: Primary Teachers are satisfied with the infrastructure of the school

Table 12. One-Sample statistics

\begin{tabular}{llllll}
\hline & N & Mean & Std. Deviation & Std. Error Mean \\
\hline Are You Satisfied With the Infrastructure of the School? & 50 & 1.44 & .497 & .021 & \\
\hline
\end{tabular}

Table 13. One-Sample test

\begin{tabular}{|c|c|c|c|c|c|c|}
\hline & \multicolumn{6}{|c|}{ Test Value $=1.5$} \\
\hline & & \multirow[t]{2}{*}{$\mathrm{df}$} & \multirow[t]{2}{*}{$\begin{array}{l}\text { Sig. } \\
\text { (2-tailed) }\end{array}$} & \multirow[t]{2}{*}{$\begin{array}{l}\text { Mean } \\
\text { Difference }\end{array}$} & \multicolumn{2}{|c|}{$\begin{array}{l}95 \% \text { Confidence Interval } \\
\text { of the Difference }\end{array}$} \\
\hline & & & & & Lower & Upper \\
\hline $\begin{array}{l}\text { Are You Satisfied With the Infrastructure } \\
\text { of the School? }\end{array}$ & -2.634 & 49 & .009 & -.055 & -.10 & -.01 \\
\hline
\end{tabular}

From the above Table 13 we can say that null hypothesis is rejected. Significance value is 0.000 which is less than standard value 0.05 . So Primary Teachers are satisfied with the infrastructure of the school.

\section{Conclusion}

The following objects were kept in mind while performing the research:-

1. Finding out the effect that job gratification has on an academician (employee)

2. Finding out the factors that underlie job satisfaction.

Hence, the research findings established that the impact job satisfaction has on academicians is major. The other finding was the relationship of degree of satisfaction of the employee in regards to salary taking in respect the experience of the member of staff. It was found here that degree of satisfaction of the employees varied significantly from person to person depending on their experience and salary.

One last conclusion that is to be brought to light is the non existence of difference of satisfaction level regarding opportunities of training between different age groups. 


\section{References}

Brikend, A. (2011). Job Satisfaction. Management Research and Practice, 3(4), 77-86.

Parvin, M. M., \& Nurul Kabir, M. M. (2011, December). Factors affecting employee job satisfaction of pharmaceutical sector. Australian Journal of Business and Management Research, 1(9), 113-123.

Rajput, S., Singhal, M., \& Tiwari, M. S. (2016). Job Satisfaction and Employee Loyalty: A study of Academicians. Asian J. Management, 7(2), 159-163.

Rizwan, M., Khan, W. M., Tarig, H. M. A., Ghaffar, A., Anjum, M. Z., \& Bajwa, E. U. (2012). Empirical study of Employee job satisfaction. Journal of Business Management, 29-35.

Khuntia, S., \& Adhikary, S. (2015). A Study on Job Satisfaction and Performance of Management Guru's of Management Colleges-with Reference to Odisha. International Journal of Research and Development - A Management Review (IJRDMR), 4(1).

Sinha, E. (2013). A research work on Employee Satisfaction measurement with special reference to KRIBHCO, Surat. 